\title{
Sociability Impact on Learner's Personality in Classroom and E- learning Environments: A Comparative Analysis to Help HRM Decisions
}

\author{
Abdul Saboor ${ }^{1}$ \\ M. Irfanullah Arfeen ${ }^{2}$ \\ Wahbeeah Mohti ${ }^{3}$
}

\begin{abstract}
The purpose of this study is to compare the sociability and its impact on learner's personality traits, in classroom and E-Learning settings to provide an insight for HRM decisions. We proposed that student's sociability level differ between classroom and e-learning environments. We also identify that sociability is a good predictor for extroversion and openness to experience. For this cross sectional explanatory research about 534 respondents are identified with purposive sampling method. Results point out that there is significant difference in learner's sociability, extroversion and openness to experience, in classroom and E-Learning environments. The study also established that sociability has statistically significant and positive relationship with openness to experience and extroversion. As there is not even a single study so far that have compared educational environment by using aforementioned variables in reference with development of personality, so the study is unique and a valuable contribution both in educational psychology and for decision making in HRM as well. The study will assist managers to find suitable personal for job. It will also help for training and development plan formation.
\end{abstract}

Keywords: Learner's personality, HRM decision, Sociability, E-Learning, Classroom, Education,

\section{INTRODUCTION}

Technological innovations have very speedily redefined the human interaction as well as how they will teach their new generations. Everything is available for just a click and physical attendance at library is no more necessary, assignments can be moved to and from professors, students can choose and study courses of their choice online and social networking has shortened distances very much. It was observed that despite of regular attendance of both the system, trainee's involvement was actively boosted by classroom based (CB) education system while E-Learning (EL) education system usually restrained it (Caspi, Chajut, Saporta, \& Beyth-Marom, 2006).

It was found that the EL could not entertain all the expectations of learning groups, development of their social knowledge, social interactions and good hands on competencies that were primarily required (Kreijns, Kirschner, and Jochems (2002). Differences in student's personality association with learning environments have also come to surface. Better results in EL were given by introvert students while on the other hand better performance in CB was shown by extrovert students (Overbaugh and lin (2006). A number of personality traits are linked

1 - PhD scholar, Superior University, Lahore, Pakistan

2 Postdoctoral Fellow, United Nations University UNU-EGOV, Guimaraes, Portugal, and Assistant Professor, QASMS,

Quaid-i-Azam University, 45320 Islamabad, Pakistan. arfeen@unu.edu

$3 \mathrm{PhD}$ scholar at Department of Management, Universidad de Evora, Portugal

\begin{tabular}{llll}
\hline JISR-MSSE & Volume 15 & Number 2 & July-Dec 2017
\end{tabular} 
with educational commitment which mainly includes conscientiousness, openness to experience (OE) and extroversion (Komarraju \& Karau, 2005). In 2005, Komarraju and Karau (2005) indicated that openness to experience (OE) elucidate huge variances of people committed to study than other personality traits. Researchers yet find student's personality development as an area of interest. In student's personality development, sociability is rated as a major factor and regrettably it is a challenge for education system to teach these personal qualities (McNabb, 1997).

Most of the former researches have produced contradictory results that were conducted with reference to association of personality traits of students in exams or its linkage for selection of education system. Benefits of EL in comparison with that of traditional CB are suspicious and advanced investigation is required in relation with student's personality development. Tough online education is better than conventional CB in many ways yet it has a disadvantage of non-contribution in personality building. The purpose behind teaching must not be limited to passing the examination instead its aim should be to produce professionals of good quality having effective communication, good administrative skill, high sociability, when they are put in professional life. In addition to indicating something about an individual's area of expertise, scholastic background may also influence judgments about one's suitability for particular job. Therefore, it is just possible that educational background may be an important factor here as well. The present research was designed to compare the level of sociability and its impact on student's personality in EL and CB environments to help out decision makers in selection situations. That's why this study is very important because it will highlight neglected side of education system which is implicit in nature but of a huge weightage in professional career.

\section{Hypotheses}

This study planned to explore following hypothesis

H1: Level of Sociability is high in classroom base students than e-learners.

H2: Classroom base students are high on personality trait extroversion, than E-Learners.

H3: Classroom base students are high on personality trait openness to experience, than e-learners.

H4: Sociability has a higher positive relationship with openness to experience in class room based students than e-learners.

H5: Sociability has a higher positive relationship with extroversion in class room based students than e-learners.

\section{Significance of the Study}

Currently, there is no strong proof available over the student's characteristics under study. Though connotation of these attributes with instruction environment has been shown by some of the students yet there is not even a single study that has quantified the difference $\mathrm{s}$ and comparison among groups. That's why; this study is unique and paramount in its nature. Consequently, it is a worthy input in educational psychology as well helpful in decision making process related with human resource development and human resource management (HRM). 


\section{LITERATURE REVIEW}

Education institutes are not only supposed to transfer skills and knowledge in the light of already defined curriculum but they also impart personality building and skills development of the students which is a hidden but counterpart of the curricula. The later part is basically an outcome of student's acquaintance with the instructors and that of students, classroom environment and techniques of study which effects student's commutation, understanding ideas and their proper expression. The failure of online education was observed in the shape of non-satisfaction of learning groups in getting hold of important competencies and their social or knowledge development (Kreijns et al. (2002). An asynchronous roadmap is used by almost all the online programs in which main tool for a student is listening or watching of a lecture by her/himself. (Purcell, Heaps, Buchanan, \& Friedrich, 2013). Student's behavior has been linked in each design by a number of studies along with determining competency of asynchronous design with that of synchronous. It was held by Chou (2012) that in synchronous set, a greater ratio of social communications took place while students of asynchronous group were noted be more auguring in assignments that were task-oriented. Again, it was showed by Hrastinski (2008) that students consume much time on debating content-related matters in the asynchronous set, while higher social support seeking behavior was noted in other set of students.

Permitting students to have better organization of their studies gives online education a commanding position over the other. A lot of students have proved that online learning is more effective for those who faces inability or problems in attending classes, thus, creating more responsibility in online students (Zapalska \& Brozik, 2006). Thus, assessing student's style of learning is an important aspect for making effective e-learning plan particularly defining there whether online class caters appropriate needs of a student or not?

Diaz and Cartnal (1999) held students who get registration under online courses are more autonomous in handling their issues than that of classroom based system merely because of having no relation with fellows makes them to be more decisive. Cattell and Kline (1977) stained that individuality is a composition of natural psychology discipline and with reference to particular human being, development can be successfully made in the areas like remembrance, learning theory, insight, remembrance (Mai \& Mai, 2002). Researches made in the decade of 1960s explicated that characters are exceptional judgment of forthcoming education recitals and counseling (Wiggins, Blackburn, \& Hackman, 1969). By taking motivation from this study, we believe that individual evaluation must be made to take benefit of classes based on internet (Kim \& Schniederjans, 2004). It was investigated by Al-Zahrani (2002) that there is a positive effect of attitude on success and effects of web on learner's success.

\section{Sociability}

Holland (1997), elucidated the type of socials person as persons who are sympathetic, caring, considerate, liberal, accountable and responsive. Social persons like to select actions which involved dealing with others like updating them, coaching, curing, explaining and building. These preferences incline to human relationships competencies and let them make their choice in choosing their professions like as psychotherapy and or coaching. Social persons have tendency and like to support others in situations like institutional service, mutual dealings or medicinal support. Dodero, Fernández, and Sanz (2003) Made comparison of effects of mixed 
style of learning and online education methods on learner's level of involvement and accomplishing of tasks. Yang, Tsai, Kim, Cho, and Laffey (2006) showed a constructive relation between sociability in online learning and motivation. Eysenck (1981) put forward a theory and proposed that stimulation is considered as a fundamental element of extroversion by which extroverts get inspired to engage and stimulate social activities on account of having intrinsic desire for sociality. Pachucki, Lena, and Tepper (2010) revealed student's perceptions regarding their creative contribution which they expressed during their college life. In observing effects on creativity, it was proved that daily routine experience and social interactions play a major part.

\section{Extroversion}

First time, Jung (1923) introduced the term 'extrovert; , persons having this type of nature were put in the category of more sociable and having good relations with other people. In ELES setting, learner's expectations and requirements differ relatively, from the face to face teaching method (Frith \& Kee, 2003). It was proved that introverted persons have much motivation and attraction towards online education when compared with extroverts (Moore \& Kearsley, 1996). In same decade, Biner, Bink, Huffman, and Dean (1995) reported that there is no link between students personality and E-learning environments .On the other hand, Kim and Schniederjans (2004) documented remarkable links among student's achievement and big five modal of personality.

It was observed by Asendorpf and Wilpers (1998) that social relationships are also affected by personality but its inverse relation could not be proved. Relationship qualities always do not predict personality traits and their changes. In the recent past, Lucas and Diener (2001), proposed extra sensitivity of extraverts in social situations than introverts and it's a good advantage to the extroverts. Furthermore, Pavot et al. (1990) proved that both introverts and extraverts enjoy social situations but extraverts adore more happiness.

\section{Openness to Experience}

There are six factors affect the openness to experience (OE): Aesthetics, vision, feelings, thoughts, ethics and actions. Zuckerman (1994) stated that five of these feature position for inner types of skill seeking, while Actions are symbolized as an outer type, despite of the fact that an interest in varied experience is carved by all of them (McCrae \& Costa Jr, 1989). Numerous personality behaviors, mostly OE, conscientiousness and extroversion are linked assurance (Komarraju \& Karau, 2005). Komarraju and Karau (2005) reported that OE elucidate variance of study very much in those individuals, who are set to undergo the experience and can accept challenges from the start to end. Moreover, openness contains active imagination, consideration of internal feelings, artistic sympathy, rational interest and partiality for diversification (McCrae \& Costa Jr, 1989). Moreover, unique ideas are triggered by openness directly to more willingness (Walczuch \& Lundgren, 2004). Openness was noted to be an appropriate predictor for proficiency of training (Barrick, Mount, \& Strauss, 1993).

A positive connotation between $\mathrm{OE}$ and sociability was noted by researchers like Furnham, Jensen, and Crump (2008). For extroversion and sociability, similar observations were made by Francis \& Pearson (1985). People having high trait of OE produce more new situations and ideas and are highly absorbing to new training and skills (Barrick \& Mount, 1991). Organizational changes are adopted by them easily (LePine, 2003) that's why marketing jobs are more

\begin{tabular}{|c|c|}
\hline July-Dec 2017 & Volume 15 \\
\hline
\end{tabular}


suited to extrovert people who adjust as per situation promptly (Wanberg \& Kammeyer-Mueller, 2000).

It is realized on the basis of literature review that in business organizations extroversion and openness has much overtone with HRM than other traits of personality. So in our proposed model only these traits have been included.

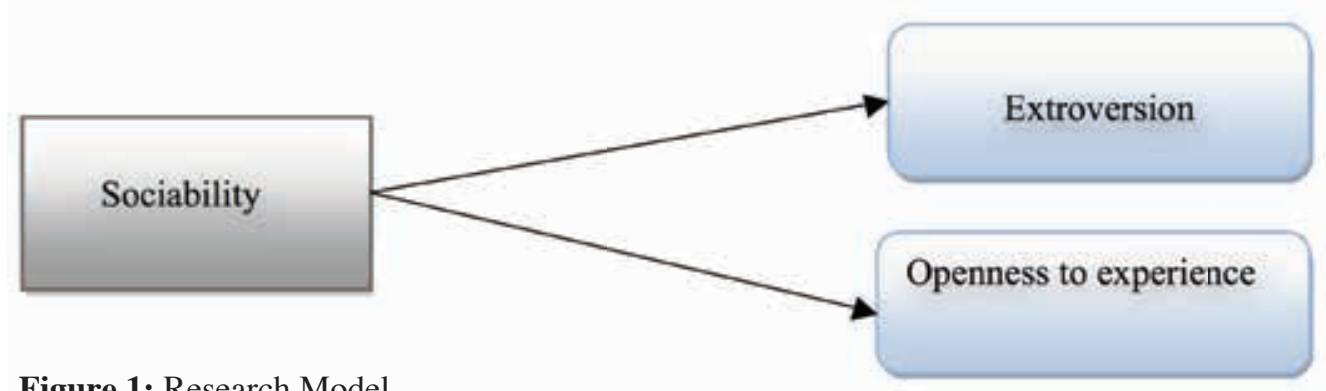

Figure 1: Research Model

\section{METHODOLOGY}

In this research purposive sampling method was used keeping in view its helpfulness in taking a uniform sample, whose units share the same characteristics. In this study, sample has been made over those students, who had completed at least 2 semesters and were jobless. There would be huge variations in student's demographics, If we had used other probability sampling methods and its ratio would be even high in case of EL education system ( as some of them might be doing job as well) so we are of the firm believe that this sampling method has helped us to diminish these disparities.

With the help of WHO Manual calculated a sample size of 534 students (267 students in each group), having $80 \%$ power of test and $95 \%$ confidence level with expected satisfactory performance in classroom to be $92.3 \%$ and in EL environment $84.6 \%$ by using formula as given below (Malhotra, 2008).

" $n=\left(Z_{\alpha / 2}+Z_{\beta}\right) 2 *\left(p_{1}\left(1-p_{1}\right)+p_{2}\left(1-p_{2}\right)\right) /\left(p_{1}-p_{2}\right)^{2} "$,

The critical value of the Normal distribution at $\alpha / 2$ is $Z \alpha / 2$ is (e.g. with confidence level $95 \%$, critical value is 1.96 and $\alpha$ is 0.05 ), while at $\beta, Z \beta$ is the critical value of normal distribution .Moreover, $\mathrm{p} 1$ and $\mathrm{p} 2$ are the proportions of both groups.

Two frames were used at time i.e. the list and the area. Population comprised of students of management sciences of COMSATS Lahore \& Vehari Campuses, University of Management \& Technology Lahore and CFE Campus Lahore for CB while Virtual University Campuses of Lahore, Multan \& Vehari for EL. Students of Master's program of these campuses who had completed at least1st two semesters spread over one year were enrolled. Student's list, their addresses and names were obtained per list frame. In this study, student was taken as unit for analysis.

From literature following research instruments can be easily acknowledged. Paper form survey was made by using questionnaire instead of online surveyed so as to collect a good sample size / participants. Instruments for sociability are adopted from the work of Cheek \&

\begin{tabular}{llll}
\hline JISR-MSSE & Volume 15 & Jumber 2 & July-Dec 2017 \\
\hline
\end{tabular}


Buss (1981). For personality traits measurement, it is adopted from John \& Srivastava (1999). In order to reduce biasness and liking/disliking of the researcher, a self- administered and structured questionnaire was used. To make it more reliable and in response items with a view of an ease to administer data, Seven Point Likert scale was adopted that contains options varying from strongly disagree to the range of strongly agree having neutral item in the middle (Jaeschke, Singer, \& Guyatt, 1990) to deliver precise score of reliability (Allen \& Seaman, 2007).

Quantified data was prepared for making analysis after collecting back the dully filled in questionnaires from the students, by entering data into SPSS version 19. For quantitative variables, Mean \pm SD was calculated and used percentage \& frequency. For compassion of items of quantitative variables between two groups, T-Test was applied. Statistical value of P $<0.05$ chains results meaningfully. In order to ascertain relationship between dependent and dependent variable Pearson coefficient of correlation was used. Moreover, sociability effects on personality of students was established with the help of linear regression analysis (Sarwar et al., 2013). To find out internal consistency of diverse scales Cronbach's alpha was used.

\section{RESULTS AND DISCUSSION}

In this research of cross sectional, explanatory research, 534 questionnaire were distributed among the students (Arbaugh \& Duray, 2002). 471 questionnaires were received back which comes to $88 \%$ of the total. After scrutiny, incomplete /improperly filled 45 questionnaire forms were ruled out, so at final 426 forms were used in making final analysis which comes to the tune of $79.7 \%$ of the sample size. After collection and rationalizing of data, it was fed in SPSS version 19 in reverse form and necessary reports were extracted. It contained response from 216 CB students and $214 \mathrm{EL}$ as expressed in below given table 1.

Table 1: Frequency Table for Mode of Study

\begin{tabular}{lrrrr}
\hline & & & \multicolumn{2}{c}{$\begin{array}{c}\text { Cumulative } \\
\text { Percent }\end{array}$} \\
& Frequency & Percent & Valid Percent & 49.8 \\
CB & 212 & 49.8 & 49.8 & 100.0 \\
EL & 214 & 50.2 & 50.2 & \\
Total & 426 & 100.0 & 100.0 & \\
\hline
\end{tabular}

Age of majority of the students was in the range of 20-25 years ( $n=360$, cumulative percentage of 84.50) while only $9.39 \%$ had ages between 26-30 year bracket. There were 18 respondents from age bracket $31-35$ years. Only 8 students had age $36-40$ years $(1.88 \%)$. It is explained in below given table 2 . 
Table 2: Frequency table for various Age Groups

\begin{tabular}{lrrrr}
\hline & Frequency & Percent & Valid Percent & Cumulative Percent \\
\hline $20-25$ years & 360 & 84.50 & 84.50 & 84.50 \\
$26-30$ years & 40 & 9.39 & 9.39 & 93.89 \\
$31-35$ years & 18 & 4.23 & 4.23 & 98.12 \\
$36-40$ years & 8 & 1.88 & 1.88 & 100.0 \\
Total & 426 & 100.0 & 100.0 & \\
\hline
\end{tabular}

Analogous tendency was noted, when it was compared between groups. No noteworthy difference $(\mathrm{p}=.520)$ between these two groups was observed with respect to age, as shown in table 3 . Thus there is no age bias among the results of current study.

Table 3: Comparison of Age between the two Groups

\begin{tabular}{|c|c|c|c|c|c|c|}
\hline & & & \multicolumn{2}{|c|}{ Mode of Study } & \multirow[b]{2}{*}{ Total } & \multirow[b]{2}{*}{$P$ Value } \\
\hline & & & CBES & ELES & & \\
\hline \multirow[t]{11}{*}{ Age Group } & $20-25$ & Count & 189 & 185 & 374 & .520 \\
\hline & years & \% within Age Group & $50.5 \%$ & $49.5 \%$ & $100.0 \%$ & \\
\hline & & $\begin{array}{l}\text { \% within Mode of } \\
\text { Study }\end{array}$ & $89.2 \%$ & $86.4 \%$ & $87.8 \%$ & \\
\hline & $26-30$ & Count & 19 & 20 & 39 & \\
\hline & years & $\%$ within Age Group & $48.7 \%$ & $51.3 \%$ & $100.0 \%$ & \\
\hline & & $\begin{array}{l}\% \text { within Mode of } \\
\text { Study }\end{array}$ & $9.0 \%$ & $9.3 \%$ & $9.2 \%$ & \\
\hline & $31-35$ & Count & 2 & 6 & 8 & \\
\hline & years & $\%$ within Age Group & $25.0 \%$ & $75.0 \%$ & $100.0 \%$ & \\
\hline & & $\begin{array}{l}\text { \% within Mode of } \\
\text { Study }\end{array}$ & $.9 \%$ & $2.8 \%$ & $1.9 \%$ & \\
\hline & $36-40$ & Count & 2 & 3 & 5 & \\
\hline & years & $\begin{array}{l}\text { \% within Age Group } \\
\% \text { within Mode of } \\
\text { Study }\end{array}$ & $\begin{array}{r}40.0 \% \\
.9 \%\end{array}$ & $\begin{array}{r}60.0 \% \\
1.4 \%\end{array}$ & $\begin{array}{r}100.0 \% \\
1.2 \%\end{array}$ & \\
\hline \multirow[t]{3}{*}{ Total } & & Count & 212 & 214 & 426 & \\
\hline & & $\%$ within Age Group & $49.8 \%$ & $50.2 \%$ & $100.0 \%$ & \\
\hline & & $\begin{array}{l}\text { \% within Mode of } \\
\text { Study }\end{array}$ & $100.0 \%$ & $100.0 \%$ & $100.0 \%$ & \\
\hline
\end{tabular}

From both the groups, majority of the students $(n=160,37.6 \%)$ had completed three semesters, which is followed by $35.9 \%$ students who had completed two semesters, at the time of filling questionnaire, as shown in table 4. However, while comparing the two groups in terms of duration of study, once again non-significant statistical difference was noted $(p=.514)$, the effect of bias due to study duration as shown in table 4 . 
Table 4: Comparison of Study Duration between the two Groups

\begin{tabular}{|c|c|c|c|c|c|c|}
\hline & & & \multicolumn{2}{|c|}{ Mode of Study } & \multirow[b]{2}{*}{ Total } & \multirow[b]{2}{*}{ Pvalue } \\
\hline & & & CBES & ELES & & \\
\hline \multirow{12}{*}{$\begin{array}{l}\text { No. of } \\
\text { Semesters }\end{array}$} & Two & Count & 82 & 71 & 153 & .514 \\
\hline & & $\%$ within No. of Semesters & $53.6 \%$ & $46.4 \%$ & $100.0 \%$ & \\
\hline & & $\%$ within Mode of Study & $38.7 \%$ & $33.2 \%$ & $35.9 \%$ & \\
\hline & Three & Count & 80 & 80 & 160 & \\
\hline & & $\%$ within No. of Semesters & $50.0 \%$ & $50.0 \%$ & $100.0 \%$ & \\
\hline & & \% within Mode of Study & $\mathbf{3 7 . 7} \%$ & $\mathbf{3 7 . 4} \%$ & $37.6 \%$ & \\
\hline & Four & Count & 36 & 46 & 82 & \\
\hline & & $\%$ within No. of Semesters & $43.9 \%$ & $56.1 \%$ & $100.0 \%$ & \\
\hline & & $\%$ within Mode of Study & $17.0 \%$ & $21.5 \%$ & $19.2 \%$ & \\
\hline & Five & Count & 14 & 17 & 31 & \\
\hline & & $\%$ within No. of Semesters & $45.2 \%$ & $54.8 \%$ & $100.0 \%$ & \\
\hline & & \% within Mode of Study & $6.6 \%$ & $7.9 \%$ & $7.3 \%$ & \\
\hline \multirow[t]{3}{*}{ Total } & & Count & 212 & 214 & 426 & \\
\hline & & $\%$ within No. of Semesters & $49.8 \%$ & $50.2 \%$ & $100.0 \%$ & \\
\hline & & $\%$ within Mode of Study & $100.0 \%$ & $100.0 \%$ & $100.0 \%$ & \\
\hline
\end{tabular}

In order to measure scale consistency, reliability test was used, initially individually for each scale and later on at the complete survey as a whole. The value for sociability on Crone Bach's Alpha value came.805, while it value was .758 for eight items Alpha scale for extroversion. Ten items scale Alpha value for openness to experience was noted to be .810 . Significantly high internal consistency of this peculiar sample is ascertained when Crone Bach Alpha value was noticed .917 for the whole full questionnaire. Nunnally, Bernstein, \& Berge (1967) stated that, a scale is reliable if it's value of reliability coefficient is $>0.7$. It is evident from below given table 5, all the values of Crone Bach's Alpha are within acceptable range.

Table 5: Reliability coefficient

\begin{tabular}{clcc}
\hline Ser. \# & \multicolumn{1}{c}{ Variable } & Total Items & Alpha \\
\hline 1 & Extroversion & 8 & .758 \\
2 & Openness to Experience & 10 & .810 \\
3 & Sociability & 10 & .805 \\
4 & Whole Questioner & it33 & .917 \\
\hline
\end{tabular}

For testing out the relationship of sociability with personality traits OE and extraversion, Pearson's coefficient of correlation ( $r$ ) was used. An abstemiously high relationship was held between extroversion and sociability at the 0.01 level (2-tailed). Moreover, a modest positive relationship for extraversion and sociability was given by correlation value $(\mathrm{r}=.507)$. Same as, the coefficient of correlation value $(\mathrm{r}=.458)$ indicate a positive correlation between $\mathrm{OE}$ and sociability. Summary of the findings is given in table 6.

Table 6: Correlation Test

\begin{tabular}{|c|c|c|c|c|}
\hline & & Sociability & Extroversion & $\begin{array}{l}\text { Openness to } \\
\text { Experience }\end{array}$ \\
\hline & Sociability & 1 & & \\
\hline & Extroversion & $.507^{*}$ & 1 & \\
\hline & $\begin{array}{c}\text { Openness to } \\
\text { Experience }\end{array}$ & $.458^{*}$ & $.412 *$ & 1 \\
\hline \multicolumn{5}{|c|}{ "*. Correlation is significant at the 0.01 level (2-tailed). } \\
\hline 84 July-Dec 2017 & & Volume 15 & Number 2 & JISR-MSSE \\
\hline
\end{tabular}


For testing the level of sociability between two groups, the $t$ test was undertaken. For sociability, the mean score $(5.21 \pm 1.12$ vs. $4.35 \pm 1.43)$ was high in $C B$ in comparison with EL and this variance was statistically substantial as given in table 7 below. Hence our first hypothesis is proved. That we acknowledged as H1: "Level of Sociability is high in classroom base students than e-learners".

Table 7: Comparison of sociability between the Groups

\begin{tabular}{llllrrr}
\hline & Mode of Study & N & Mean & $\begin{array}{c}\text { Std. } \\
\text { Deviation }\end{array}$ & $\begin{array}{c}\text { Std. Error of } \\
\text { Mean }\end{array}$ & P value \\
\hline \multirow{2}{*}{ Sociability } & CBES & 212 & 5.2057 & 1.17798 & .08090 & .000 \\
& ELES & 214 & 4.3505 & 1.43215 & .09790 & \\
\hline
\end{tabular}

Alike opinion was made in terms of outcome variables. The mean score for Extroversion $(4.79 \pm 1.06$ vs. $4.34 \pm 1.24)$ and $\mathrm{OE}(5.05 \pm 1.01$ vs. $4.63 \pm 1.16)$ was also expressively high in CB students in comparison with students of ELES. Thus, our 2nd hypothesis H2: "Classroom base students are high on personality trait extroversion, than e-learners" proves true. It has been proved by the results that $\mathrm{CB}$ students are high on personality traits and $\mathrm{OE}$ as well. Therefore our third hypothesis H3: "Classroom base students are high on personality trait openness to experience, than e-learners" is proved as well. Results have been amassed in below table 8 .

Table 8: Comparison of Extroversion and Openness to Experience between the Groups

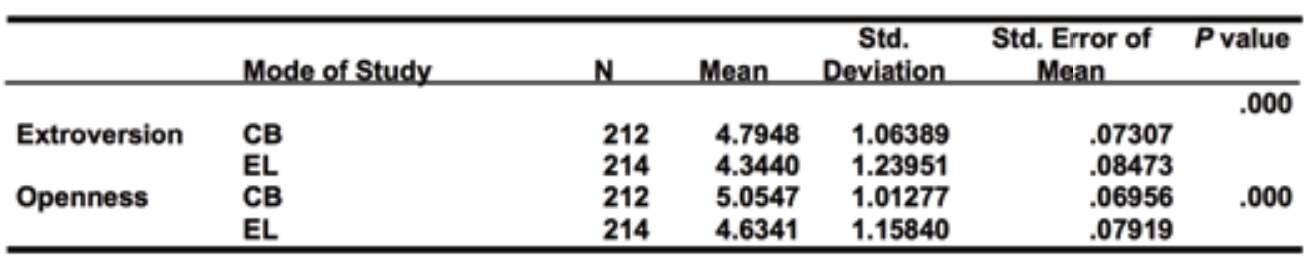

An ominously high positive impact ( $\mathrm{R}$ square) with $\mathrm{OE}$ was given by regression analysis (.325 vs. .101; $\mathrm{p}=.000$ ), in CB students in comparison with EL. Resultantly, our 4th hypothesis is proved that was stated as H4: "Sociability has a higher positive relationship with openness to experience in classroom based students than e-learners". It was also shown by regression analysis that Sociability had knowingly high positive impact ( $\mathrm{R}$ square) with extroversion (.322 vs. .169; $\mathrm{p}=.000)$ in CB students while comparing with EL. Hence our 5th hypothesis is also proved that was stated as H5: "Sociability has a higher positive relationship with extroversion in class room based students than e-learners". Results have been summarized table 9 below.

Table 9: Results of linear regression

\begin{tabular}{|c|c|c|c|c|c|}
\hline Sociability & $\begin{array}{l}\text { Mode of Study } \\
\text { CB }\end{array}$ & $\begin{array}{l}\text { Dependent } \\
\text { Variable } \\
\text { Extroversion }\end{array}$ & $\begin{array}{r}\text { R Square } \\
.322 \\
\end{array}$ & $\begin{array}{l}\text { Standardized } \\
\text { Coefficients } \\
\text { Beta } \\
\end{array}$ & $\begin{array}{c}P \\
\text { value } \\
.000 \\
\end{array}$ \\
\hline Sociability & $\begin{array}{l}\text { EL } \\
\text { CB } \\
\text { EL }\end{array}$ & Openness & $\begin{array}{l}.169 \\
.325 \\
.101\end{array}$ & $\begin{array}{l}.416 \\
.573 \\
.324\end{array}$ & .000 \\
\hline
\end{tabular}

Hypotheses were tested with the help of t-test and regression analysis. Hypothesis were supported for $\mathrm{p}<0.05$.

\begin{tabular}{llll}
\hline JISR-MSSE & Volume 15 & Number 2 & July-Dec 2017
\end{tabular}




\section{DISCUSSION}

The actual purpose of the study was to compare the classroom-based education with E-Learning with respect to learner's sociability and its impact thereof, on personality traits (extroversion, openness to experience) of students. A number of conclusions and inferences can be made from this study, regarding student's sociability and personality traits. It is evident from results that sociability level is high in students of class room based traditional education system in comparison with learners on web (Sánchez, Salinas, Contreras, \& Meyer, 2011). Moreover, it is also proved that there is a positive association between sociability and openness to experience (Furnham et al., 2008). Statistically significant association of sociability with extroversion is also very clear ( Lucas et al., 2000). Thus the instant research strengthens the prior research in this sphere. However, this study is unique as it makes comparison of sociability effect between face to face learners in traditional class room system and that of web learners. Moreover, exploration about sociability effect on both the types of learner's personality has also been made in this research. Results showed that students that have high score in sociability have propensity to score high in extroversion and that of openness to experience on personalities big five model. It is also proved that sociability has higher positive influence on personality traits of class room based students that that of e-learners. Thus, it is necessary that the teachers should adopt and use teaching methodologies having more interaction with the students and among the students. Similar HR Managers should make such development programs, a part of employee development.

\section{CONCLUSION AND RECOMMENDATION}

As a conclusion, it is held that sociability is a virtuous forecaster for student's personality traits and in comparison with e-learning; Class-room based education is superior in expressions of student's sociability and its effects on their personality.

\section{Managerial Implications}

Though traits of personality are almost established when observed across the time, yet it is a challenging point for the decision makers to make their employees a low cost and valuable asset for the organization. For example sociability is of key value when it is intended to hire a person for marketing job and similarly openness to experience and extroversion should be given due weightage while bringing some innovation and change or establishment of new business plan. If at this time, new hiring is not required, even then Manager must make this sorting within existing work force for not only their development rather their proper and beneficial placement as well.

\section{Implication in Education Sector}

Now E-Learning is also established in Pakistan up to a greater extent as most of the universities are using Learning Management System (LMS). In this nexus, it is pertinent to mention Virtual University of Pakistan that is totally using LMS should make some alteration in teaching methodology by introducing a good blend learning so as to help out the students personality development and enabling them to compete the students of traditional class room based learning system. 


\section{Limitations of the Study}

In the recent past, in web based education system virtual class-rooms have been introduced so as to create a sense of traditional class rooms to give students an prospect of sharing their ideas and getting rid of loneliness \& shyness (Subramaniam \& Kandasamy, 2011). However, such students have not been included in this study and are a limitation to this study. Therefore, recurrence of this study is needed among those students so as to effectively evaluate the effectiveness of such virtual class rooms and their role in personality development. Researchers might also include other remaining side of personality from Big Five Model, in future, so as to bring a clearer picture. Moderator variables should like social and financial position of the student's should be used. Non- accounting of socioeconomic variable of is a major limitation in this study, so it must be used as moderator in future studies. A limitation point is this, the data collection was made from that of Central and Southern Punjab, in future researches, collection of sample should be made from a large area so as to bring good results and understanding from this phenomenon.

\section{ACKNOWLEDGEMENT}

This paper is a result of the project "SmartEGOV: Harnessing EGOV for Smart Governance (Foundations, methods, Tools) / NORTE-01-0145-FEDER-000037", supported by Norte Portugal Regional Operational Programme (NORTE 2020), under the PORTUGAL 2020 Partnership Agreement, through the European Regional Development Fund (EFDR). It was also supported in part by funding from Tallinn University of Technology, Project B42; OGI Open Government Intelligence project in the EU Horizon 2020 framework program, grant agreement 693849.

\section{REFERENCES}

Allen, I. E., \& Seaman, C. A. (2007). Likert scales and data analyses. Quality Progress, 40(7), 64-65.

Al-Zahrani, A. (2002). The effects of the use of the worldwide web on the achievement of the learners of the syllabus of educational technologies at the Teacher's Training College in Riyadh. MA. King Saud University, Saudi Arabia.

Arbaugh, J. B., \& Duray, R. (2002). Technological and structural characteristics, student learning and satisfaction with web-based courses an exploratory study of two on-line MBA programs. Management Learning, 33(3), 331-347.

Asendorpf, J. B., \& Wilpers, S. (1998). Personality effects on social relationships. Journal of personality and social psychology, 74(6), 1531.

Barnes, F. B., Preziosi, R. C., \& Gooden, D. J. (2004). An examination of the learning styles of online MBA students and their preferred course delivery methods. New Horizons in Adult Education and Human Resource Development, 18(2), 19-30.

Barrick, M. R., Mount, M. K., \& Strauss, J. P. (1993). Conscientiousness and performance of sales representatives: Test of the mediating effects of goal setting. Journal of Applied Psychology, 78(5), 715.

Biner, P. M., Bink, M. L., Huffman, M. L., \& Dean, R. S. (1995). Personality characteristics differentiating and predicting the achievement of televised-course students and traditional-course students 1. American Journal of Distance Education, 9(2), 46-60.

Caspi, A., Chajut, E., Saporta, K., \& Beyth-Marom, R. (2006). The influence of personality on social participation in learning environments. Learning and Individual Differences, 16(2), 129-144. 
Cattell, R. B., \& Kline, P. E. (1977). The scientific analysis of personality and motivation: Academic Press.

Chamorro-Premuzic, T., Moutafi, J., \& Furnham, A. (2005). The relationship between personality traits, subjectively-assessed and fluid intelligence. Personality and Individual Differences, 38(7), 1517-1528.

Diaz, D. P., \& Cartnal, R. B. (1999). Students' learning styles in two classes: Online distance learning and equivalent on-campus. College Teaching, 47(4), 130-135.

Dobbs, R. R., Waid, C. A., \& del Carmen, A. (2009). Students' Perceptions of Online Courses. Quarterly Review of Distance Education, 10(1), 9-26.

Dodero, J. M., Fernández, C., \& Sanz, D. (2003). An experience on students' participation in blended vs. online styles of learning. ACM SIGCSE Bulletin, 35(4), 39-42.

Entwistle, N. (1972). PERSONALITY AND ACADEMIC ATTAINMENT** British Journal of Educational Psychology, 42(2), 137-151.

Eysenck, H. J. (1981). A model for personality: Cambridge Univ Press.

Francis, L. J., \& Pearson, P. R. (1985). Extraversion and religiosity. The Journal of social psychology, 125(2), 269-270.

Frith, K. H., \& Kee, C. C. (2003). The effect of communication on nursing student outcomes in a web-based course. The Journal of nursing education, 42(8),350-358.

Furnham, A., Chamorro-Premuzic, T., \& McDougall, F. (2002). Personality, cognitive ability, and beliefs about intelligence as predictors of academic performance. Learning and Individual Differences, 14(1), 47-64.

Garland, K. V. (2010). E-learning vs. classroom instruction in infection control in a dental hygiene program. Journal of Dental Education, 74(6), 637-643.

Hale, L. S., Mirakian, E. A., \& Day, D. B. (2009). Online vs. classroom instruction: student satisfaction and learning outcomes in an undergraduate Allied Health pharmacology course. Journal of Allied Health, 38(2), 36E-42E.

Holland, J. L. (1997). Making vocational choices: A theory of vocational personalities and work environments: Psychological Assessment Resources.

Hrastinski, S. (2008). The potential of synchronous communication to enhance participation in online discussions: A case study of two e-learning courses. Information \& Management, 45(7), 499-506.

Jaeschke, R., Singer, J., \& Guyatt, G. H. (1990). A comparison of seven-point and visual analogue scales: data from a randomized trial. Controlled clinical trials, 11(1),43-51.

Jung, C. G. (1923). Psychological types: or the psychology of individuation.

Kim, E. B., \& Schniederjans, M. J. (2004). The role of personality in web-based distance education courses. Communications of the ACM, 47(3), 95-98.

Komarraju, M., \& Karau, S. J. (2005). The relationship between the big five personality traits and academic motivation. Personality and Individual Differences, 39(3), 557-567.

Kreijns, K., Kirschner, P. A., \& Jochems, W. (2002). The sociability of computer-supported collaborative learning environments. Educational Technology \& Society, 5(1), 8-22.

LePine, J. A. (2003). Team adaptation and postchange performance: effects of team composition in terms of members' cognitive ability and personality. Journal of applied psychology, 88(1), 27.

Liu, M. (2012). Predicting effects of personality traits, self-esteem, language class risk-taking and sociability on Chinese university EFL learners' performance in English. Journal of Second Language Teaching \& Research, 1(1), 30-57. 
Lounsbury, J. W., Sundstrom, E., Loveland, J. M., \& Gibson, L. W. (2003). Intelligence, Big Five" personality traits, and work drive as predictors of course grade. Personality and Individual Differences, 35(6), 1231-1239.

Lucas, R. E., Diener, E., Grob, A., Suh, E. M., \& Shao, L. (2000). Cross-cultural evidence for the fundamental features of extraversion. Journal of Personality and Social Psychology, 79(3), 452.

Lucas, R.E., \& Diener, E. (2001). Understanding extraverts' enjoyment of social situations: the importance of pleasantness. Journal of personality and social psychology, 81(2), 343.

Mai, L.-W., \& Mai, L.-C. (2002). The personality attributes and leisure activities of taiwanese internet users. International Journal of Applied Marketing, 1(1), 69-82.

Malhotra, N. K. (2008). Marketing Research: An Applied Orientation, 5/E: Pearson Education India.

McCrae, R. R., \& Costa Jr, P. T. (1989). Rotation to maximize the construct validity of factors in the NEO Personality Inventory. Multivariate Behavioral Research, 24(1), 107-124.

McNabb, J. G. (1997). Key affective behaviors of students as identified by a select group of secondary school teachers using SCANS categories.

Moore, M. G., \& Kearsley, G. (1996). Distance education: A systems view Wadsworth. Belmont, $C A$.

Mount, M. K., Barrick, M. R., \& Strauss, J. P. (1994). Validity of observer ratings of the big five personality factors. Journal of Applied Psychology, 79(2), 272.

Nunnally, J. C., Bernstein, I. H., \& Berge, J. M. t. (1967). Psychometric theory (Vol. 226): McGraw-Hill New York.

Pachucki, M. A., Lena, J. C., \& Tepper, S. J. (2010). Creativity narratives among college students: sociability and everyday creativity. The Sociological Quarterly, 51(1),122-149.

Paunonen, S. V., \& Ashton, M. C. (2001). Big Five predictors of academic achievement. Journal of Research in Personality, 35(1), 78-90.

Pavot, W., Diener, E., \& Fujita, F. (1990). Extraversion and happiness. Personality and Individual Differences, 11(12), 1299-1306.

Purcell, K., Heaps, A., Buchanan, J., \& Friedrich, L. (2013). How teachers are using technology at home and in their classrooms. Washington, DC: Pew Research Center's Internet \& American Life Project.

Sánchez, J., Salinas, A., Contreras, D., \& Meyer, E. (2011). Does the new digital generation of learners exist? A qualitative study. British Journal of Educational Technology, 42(4), 543-556.

Sánchez, M. M., Rejano, E. I., \& Rodríguez, Y. T. (2001). Personality and academic productivity in the university student. Social Behavior and Personality: an international journal, 29(3), 299-305.

Sarwar, A., Hameed, S., \& Aftab, H. (2013). Study to Explore the Impact of Personality Traits on Employee Turnover in Public and Private Sector. Middle-East Journal of Scientific Research, 16(9), 1249-1254.

Subramaniam, N. K., \& Kandasamy, M. (2011). The virtual classroom: A catalyst for institutional transformation. Australasian journal of educational technology, 27(8),1388-1412.

Thomas, H., Simmons, R., Jin, G., Almeda, A., \& Mannos, A. (2005). Comparison of student outcomes for a classroom-based vs. an internet-based construction safety course. The Journal of SH\&E Research, 2(1), 1-15. 
Urtel, M. G. (2008). Assessing Academic Performance between Traditional and Distance Education Course Formats. Educational Technology \& Society, 11(1), 322-330.

Walczuch, R., \& Lundgren, H. (2004). Psychological antecedents of institution-based consumer trust in e-retailing. Information \& Management, 42(1), 159-177.

Wanberg, C. R., \& Kammeyer-Mueller, J. D. (2000). Predictors and outcomes of proactivity in the socialization process. Journal of applied psychology, 85(3), 373.

Wiggins, N., Blackburn, M., \& Hackman, J. R. (1969). Prediction of first-year graduate success in psychology: Peer ratings. The Journal of Educational Research, 81-85.

Zapalska, A., \& Brozik, D. (2006). Learning styles and online education. Campus-Wide Information Systems, 23(5), 325-335.

Zuckerman, M. (1994). Behavioral expressions and biosocial bases of sensation seeking: Cambridge university press. 